\title{
KLASYFIKACJA TYPOLOGICZNA KREDYTOBIORCÓW HIPOTECZNYCH Z WYKORZYSTANIEM MODELI KLAS UKRYTYCH
}

\begin{abstract}
Streszczenie. Posiadacze kredytów mieszkaniowych stanowią ponad 6 proc. indywidualnych klientów banków. W potocznej opinii grupa ta uznawana jest za homogeniczną. Jednak cechy socjodemograficzne nie tylko nie wyjaśniają, ale wręcz maskują różnicowane uwarunkowania decyzji podejmowanych przez kredytobiorców mieszkaniowych na rynku finansowym. Czynniki różnicujące to profil psychograficzny, postawa wobec ryzyka, wiedza o finansach, przezorność, skłonność do zadłużania się i oszczędzania. Celem badań było wyodrębnienie jednorodnych segmentów posiadaczy kredytów mieszkaniowych pod względem uwarunkowań decyzji konsumenckich na rynku finansowym. Wyodrębniono pięć homogenicznych grup kredytobiorców mieszkaniowych pod względem uwarunkowań i motywów decyzji na rynku finansowym. Segmentację przeprowadzono z wykorzystaniem modeli klas ukrytych (LCA). Modele klas ukrytych umożliwiły identyfikację podtypów cech powiązanych ze sobą, które w tradycyjnym ujęcie nie są obserwowalne. Badania wykonano metodą CAPI na ogólnopolskiej reprezentatywnej próbie posiadaczy kredytów mieszkaniowych $\mathrm{N}=900$, z czego $\mathrm{N}=800$ stanowili kredytobiorcy $\mathrm{CHF}$, natomiast $\mathrm{N}=100$ kredytobiorcy PLN. Badania zrealizował TNS Polska w marcu 2014 r. oraz w marcu 2015r. (druga fala).
\end{abstract}

Słowa kluczowe: kredytobiorcy hipoteczni, klasyfikacja typologiczna, model klas ukrytych JEL: C38, E03, G20

\section{WPROWADZENIE}

Decyzje gospodarstw domowych dotyczące zakupu mieszkania/domu, a w związku z tym zaciągnięcia kredytu są najważniejszymi wśród wszystkich decyzji finansowych, jakie podejmują gospodarstwa domowe (Antonides, Raaij 1998: 432). Motywy ich podejmowania zajmują ważne miejsce w teoriach zachowań finansowych. Keynes 1936: 56-99, Browning, Lusardi 1996: 1797). Shefrin i Thaler (1988: 609-643) w teorii księgowania mentalnego postulowali, że odzwierciedleniem motywów są określone decyzje finansowe konsumentów.

*Wydział Nauk Ekonomicznych, Szkoła Główna Gospodarstwa Wiejskiego, marcin_idzik@, sggw.pl

** Związek Banków Polskich, jacek.gieorgica@zbp.pl 
W teorii zachowań finansowych dochód jest podstawowym czynnikiem warunkującym decyzje konsumentów. W rożnych postaciach występuje on u Keynesa (1936: 56-99), w psychologicznej teorii konsumpcji Katony i oczywiście w hipotezie dochodu permanentnego. Jednak z badań zrealizowanych przez autorów niniejszego opracowania wynika, że dochód, czy też inne cechy socjodmograficzne nie wyjaśniają uwarunkowań decyzji finansowych dotyczących wyboru waluty kredytu mieszkaniowego. Grupa kredytobiorców hipotecznych posiadających kredyty w PLN oraz CHF jest homogeniczna pod względem większości cech określających ich status społeczno-ekonomiczny. W strukturze LtV także nie ma istotnych różnic między grupami. W obu grupach wybór waluty kredytu przebiegał według podobnego modelu decyzyjnego, jednak poszczególni kredytobiorcy podejmowali odmienne decyzje odnośnie wyboru waluty kredytu.

W związku z powyższym autorzy ukierunkowali analizę w stronę teorii samokontroli, gdzie decyzje finansowe są wypadkową działania dwóch części osobowości konsumenta o rożnych preferencjach międzyokresowych (Thaler, Shefrin 1981: 392-406). W tym ujęciu Strotz podzielił ludzi na „naiwnych” i „wysublimowanych" - w zależności od tego, czy zdawali sobie sprawę z dwoistości swoich preferencji i próbowali sprawować samokontrolę nad własnymi decyzjami (Bańbuła 2006: 29-40). Ten nieobserwowalny w ujęciu cech socjodemograficznych podział na „naiwnych" i ,wysublimowanych" możliwy jest do identyfikacji w modelu w postaci tzw. klasy ukrytej. Kamakura (2006: 121-132) i Shefrin (1988: 609-643) wykazali ponadto, że ten podział zależy głownie od czynników subiektywnych, np. postaw, a w mniejszym stopniu od profilu socjodemograficznego czy poziomu dochodów. Badania empiryczne związane z teorią społecznych reprezentacji wykazały także, że w społeczeństwie dominują przeciwstawne postawy w zachowaniach finansowych: prooszczędnościowa i prokonsumpcyjna, a ponadto postawa związana $\mathrm{z}$ awersją do ryzyka i postawa akceptująca ryzyko (Webley, Nyhus 2001: 96-99).

Dotychczas w Polsce nie przeprowadzono badań, mających na celu identyfikację homogenicznych grup konsumentów pod względem uwarunkowań decyzji dotyczącej wyboru waluty kredytu mieszkaniowego. Nie podejmowano także prac zmierzających do identyfikacji motywów zadłużania się w określonej walucie czy też oceny uwarunkowań tych motywów. Zagadnienia te nie były brane pod uwagę w badaniach ekonometrycznych, mimo że zajmują obecnie istotne miejsce w publicznej dyskusji. Istnieje potrzeba identyfikacji faktycznych uwarunkowań decyzji konsumenckich w tym zakresie, w tym także związanych z przebiegiem całego procesu udzielania kredytu mieszkaniowego.

Wnioski w tym zakresie mogą służyć lepszemu poznaniu złożonych zjawisk społecznych na runku finansowym, wspomagać proces komunikacji, a także identyfikacji potencjalnych zagrożeń.

Celem artykułu jest identyfikacja i wyodrębnienie jednorodnych segmentów posiadaczy kredytów mieszkaniowych pod względem uwarunkowań wyboru waluty 
kredytu Przeprowadzona analiza dotyczy konkretnych zachowań i stanów, które prowadzą do decyzji o zaciągnięciu kredytu mieszkaniowego w złotych polskich lub we frankach szwajcarskich. Ponadto w badaniach poszukiwano odpowiedzi na pytania: Jakimi motywami kierowali się kredytobiorcy przy wyborze waluty kredytu mieszkaniowego? W jaki sposób przebiegał proces związany z udzieleniem kredytu mieszkaniowego? Jakie czynniki w największym stopniu różnicują kredytobiorców mieszkaniowych? Jaki był poziom percepcji zagrożeń w grupie kredytobiorców mieszkaniowych PLN oraz CHF? W opracowaniu zweryfikowano następującą hipotezę: konsumenci spłacający kredyty walutowe stanowią grupę homogeniczną.

W analizie ekonometrycznej posłużono się modelem klas ukrytych (LCA). W literaturze polskiej zastosowanie modeli klas ukrytych jest jeszcze bardzo wąsko opisane i wymaga wielu prac badawczych. Jednocześnie wyniki dotychczasowych badań pozwalają stwierdzić, że modele klas ukrytych dają możliwości segmentacji w oparciu o ocenę postaw i preferencji (Singh 2010: 54-62), które nie są obserwowalne i wprost mierzalne. To tej grupy zjawisk należą uwarunkowania decyzji kredytowych konsumentów spłacających kredyty we frankach szwajcarskich oraz złotych polskich.

\section{METODYKA BADAŃ}

Smith już w 1956 r. pisał, że: „segmentacja rynku jest ujęciem homogenicznego rynku, jako określonej liczby mniejszych homogenicznych rynków ze względu na ich reakcje na preferencje produktowe" (Smith 1956: 3-8). W omawianym przypadku do opisu istoty badanych procesów został zaproponowany model klas ukrytych. Przeprowadzona klasyfikacja typologiczna miała funkcję opisową. Segmenty zostały zidentyfikowane post hoc, po wyodrębnieniu kryteriów segmentacyjnych. Po uzyskaniu segmentów dokonano ich profilowania. Konieczność podejścia post hoc wynika $z$ braku możliwości zdefiniowania wartości lub poziomów zmiennych segmentacyjnych. Dla przykładu, poszukiwanie korzyści i uwarunkowań decyzji kredytowych konsumentów jest nowym, niezbadanym dotychczas zjawiskiem, dlatego zastosowano różne kryteria pomiaru korzyści, w celu wyłonienia niezależnych wymiarów określających poszukiwane przez konsumenta benefity związane z określoną decyzją.

Pomiar kryteriów obejmował zarówno cechy obserwowane i bezpośrednio mierzalne (behawioralne) oraz nieobserwowalne - cechy psychograficzne oraz ukryte reakcje na ofertę kredytu mieszkaniowego. Klasyfikację przeprowadzono w oparciu o podmiotowe oraz przedmiotowe kryteria segmentacyjne. Kryteria podmiotowe - psychografia i styl życia, wiedza o finansach, preferencje wobec podejmowania ryzyka, dotychczasowe doświadczenia z bankami, sposób zarządzania budżetem gospodarstwa domowego. Kryteria przedmiotowe - reakcje rynkowe konsumenta (reakcje na ofertę produktu kredytowego, uwarunkowania 
zaufania do banków, samoocena ryzyka, skłonność do zadłużania się vs. oszczędzania w konkretnych sytuacjach rynkowych i osobistych, przezorność, opinie o bankach i ich uwarunkowania). Analizę wykonano w module Syntax programu LatentGOLD 4.5 (Vermunt, Magidson 2008: 18-26).

\section{1. Źródła danych empirycznych}

Źródło danych empirycznych stanowią wyniki badań ogólnopolskich na reprezentatywnej próbie posiadaczy kredytów mieszkaniowych, z czego N=800 stanowili kredytobiorcy CHF, natomiast N=100 kredytobiorcy PLN. Badanie zostało zrealizowane na przełomie marca i kwietnia 2014 r. oraz w marcu 2015 r (druga fala). w domach respondentów metodą CAPI (wywiady bezpośrednie wspomagane komputerowo. Badania terenowe zrealizował TNS Polska. Próba miała charakter ogólnopolski. Uwzględniono takie parametry jak: województwo, wielkość miejscowości, płeć i wiek respondenta. Struktura próby została określona na podstawie wyników sprawozdawczych Biura Informacji Kredytowej oraz ogólnopolskich badań Audyt Bankowości Detalicznej, liczebność N=12000 tak, aby rozkład cech w próbie odpowiadał rozkładowi cech w populacji generalnej kredytobiorców. Zachowano reprezentatywność typologiczną, reprezentatywność pod względem zależności statystycznych, a także pod względem daty udzielenia kredytu.

\subsection{Metody analizy danych}

W opracowaniu analizę segmentacyjną przeprowadzono z wykorzystaniem modeli klas ukrytych (LCA). Rozwiązanie to ma szczególne zastosowanie w przypadku segmentacji post hoc, w której identyfikacja segmentów następuje na podstawie siły i kierunku reakcji konsumenta na wyróżnione instrumenty marketingu mix. Uzyskane segmenty są wówczas jednorodne ze względu na estymowaną funkcję reakcji. W przypadku modeli klas ukrytych nie ma także potrzeby definiowania ad hoc określonej liczby wyróżnionych klas (Hagenaars, McCutcheon 2002: 2-41). Zaletą analizy klas ukrytych jest probabilistyczna klasyfikacja przypadków na podstawie prawdopodobieństwa przynależności do klas ukrytych estymowanych bezpośrednio na podstawie modelu, mieszany charakter zmiennych stanowiących kryteria segmentacji oraz możliwość równoległego włączenia do analizy opisowych zmiennych kowariancyjnych.

Analiza ukrytych klas służy identyfikacji podtypów w powiązanych ze sobą wielowymiarowych kategorialnych cechach. Klasy latentne są to segmenty nieobserwowalne (ukryte). Tym, co faktycznie jest obserwowane, są ich symptomy, mierniki. Ukryta klasa określa pewną abstrakcyjną cechę lub charakterystykę, która nie może być zaobserwowana bezpośrednio, jednak jest czynnikiem różnicującym poszczególne obiekty (Bollen 1989: 35-47, Lubke 2005: 21-39, Keel i inni 
2004: 192-200). Przykładami zmiennych ukrytych są między innymi: preferencje, nastawienie intencje zachowań czy cechy osobowości (Formann 2003: 549-559). Takiego rodzaju charakterystyki mogą zostać zmierzone tylko pośrednio, np. poprzez kwestionariusz skonstruowany w taki sposób, by otrzymać odpowiedzi powiązane z nastawieniem czy preferencjami.

Model kas ukrytych składa się z części strukturalnej modelu oraz części pomiarowej. W ramach części strukturalnej modelu szacuje się prawdopodobieństwo przynależności danego przypadku do danej klasy. W efekcie otrzymujemy odsetek populacji w danej klasie ukrytej. W części pomiarowej określane jest prawdopodobieństwo $k$-tej odpowiedzi na $i$-te pytanie pod warunkiem przynależności do $c$-tej klasy ukrytej. Część pomiarowa modelu opisuje związek między odpowiedzią na $i$-tą zmienną wskaźnikową a przynależnością do $c$-tej klasy ukrytej, ponadto stanowi podstawę opisu c-tej klasy (Vermunt, Magidson 2005: 9 ).

Postępowanie w ramach analizy klas ukrytych sprowadza się do wyodrębnienia segmentów i oszacowania parametrów funkcji gęstości charakterystycznych dla każdego z nich. Funkcja gęstości dla klas ukrytych jest podstawą określenia warunkowego prawdopodobieństwa wystąpienia obserwowanych wartości w danej klasie (Vermunt, Magidson 2003: 83-121). Postać modelu ogólnego jest opisana równaniem (wzór 1) (Yang 2006: 1090-1104):

$$
f\left(y_{i} \mid z_{i}\right)=\sum_{x=1}^{K} P\left(x \mid z_{i}\right) f\left(y_{i} \mid z_{i}\right)=\sum_{x=1}^{K} P\left(x \mid z_{i}\right) \prod_{h=1}^{H} f\left(y_{i h} \mid x, z_{i}\right)
$$

gdzie:

$y_{i}$ - zmienne zależne (wskaźniki klas ukrytych),

$z_{i}$-zmienne niezależne (predyktory),

$x$ - klasy ukryte (od 1 do K).

Model z ukrytymi zmiennymi jest nieliniową ścieżką analizy problemu. Model zawiera jedną lub więcej ukrytych zmiennych reprezentujących charakterystyki, które nie są obserwowalne. Istnieją dwa podstawowe założenia definiujące przyczynowy mechanizm, któremu podlegają odpowiedzi. Pierwsze zakłada, że odpowiedzi dotyczące wskaźników są wynikiem wpływu jednostki na ukrytą zmienną. Zgodnie z drugim założeniem, po wprowadzeniu zmiennych ukrytych, zmienne obserwowalne nie mają ze sobą nic wspólnego, co jest często referowane jako aksjomat lokalnej niezależności (Kaplan 2003: 81-114).

Zakłada się, że rozkład zmiennych obserwowalnych w badanej populacji jest mieszanką kilku rozkładów wchodzących do niej subpopulacji (wzór 2). Celem analizy jest wyodrębnienie skończonej liczby rozkładów cząstkowych, które składają się na rozkład w populacji (Vermunt, Magidson 2003: 83-121). W modelu klas ukrytych zakłada się, że jednostki opisywane binarnymi, nominalnymi czy 
też porządkowymi cechami należą do danej liczby nieznanych segmentów. Model klas ukrytych jest następujący:

$$
f\left(y_{i} \mid z_{i}^{\text {cov }}\right)=\sum_{x=1}^{K} P\left(x \mid z_{i}^{\text {cov }}\right) \prod_{t=1}^{T} f\left(y_{i t} \mid x\right)
$$

gdzie:

$y_{i}-$ zmienne zależne (wskaźniki klas ukrytych),

$z_{i}^{\text {cov }}$ - zmienne niezależne (kowarianty),

$x$ - klasy ukryte (od 1 do K).

Funkcja gęstości dla klas ukrytych jest podstawą określenia warunkowego prawdopodobieństwa przypisania przypadku do danej klasy. W tym celu wykorzystuje się metodę największej wiarygodności, która maksymalizuje dla danego modelu prawdopodobieństwo wystąpienia takich danych jak w obserwowanej próbie (Kaplan 2003: 81-114, Langeheine 2002: 323). W celu znalezienia wartości parametrów maksymalizujących funkcję wiarygodności najczęściej używa się algorytmu maksymalizacji wartości oczekiwanej(expectation-maximization - EM) oraz metody Newtona-Rapsona (NR) (Dempster Laird, Rubin 1977: 1-38, Vermunt, Magidson 2008: 28-35). Po oszacowaniu parametrów rozkładu oblicza się prawdopodobieństwa, że dany przypadek pochodzi z danej homogenicznej grupy. Prawdopodobieństwo przynależności do skupień jest szacowane na podstawie modelu (wzór 3). Model regresyjnych klas ukrytych jest przedstawiony za pomocą równania:

$$
f\left(y_{i} \mid z_{i}^{\text {cov }}, z_{i}^{\text {pred }}\right)=\sum_{x=1}^{K} P\left(x \mid z_{i}^{\text {cov }}\right) \prod_{t=1}^{T} f\left(y_{i t} \mid x, z_{i t}^{\text {pred }}\right)
$$

gdzie:

$y_{i}$ - zmienne zależne (wskaźniki klas ukrytych),

$z_{i}^{\text {cov }}$ - zmienne niezależne (kowarianty),

$z_{i}^{\text {pred }}-$ zmienne niezależne (predyktory),

$x$ - klasy ukryte (od 1 do K).

Fakt, że jest to model estymowany za pomocą metody największej wiarogodności, a nie algorytm, pozwala w sposób niearbitralny ustalić optymalną liczbę segmentów w oparciu o zestaw miar dopasowania modelu. Jest to jedną z podstawowych zalet tego podejścia w porównaniu z tradycyjnymi rozwiązaniami, takimi jak segmentacja k-średnich (Magdison, Vermunt, Tran 2007: 235-242, Tofighi, Enders 2007: 317-341). Finalnie, dąży się do takiego oszacowania parametrów modelu, aby przypadki zaliczane do tej samej klasy były homogeniczne ze względu na określone, wybrane kryteria, podczas gdy przypadki należące do innych klas 
latentnych maksymalnie się od siebie różniły (Bartholomew, Knott 2002: 231267). Dostępnych jest kilka metod wyboru najlepszego rozwiązania. Podstawą oceny modeli klas ukrytych jest analiza tablicy kontyngencji. Jedną z metod oceny jest miara jakości dopasowania bazująca na statystyce chi-kwadrat (wzór 4).

$$
G^{2}=\sum_{s=1}^{S} 2 f(s) \ln [f(s) / e(s)] \sim \chi^{2}, v=S-k
$$

gdzie:

$G^{2}$ - statystyka chi-kwadrat wyrażona w postaci ilorazu wiarygodności, $S$ - liczba wzorów odpowiedzi = liczba elementów tablicy kontyngencji, $f(s)$ - empiryczna liczebność w komórce $s$ tablicy kontyngencji, $e(s)$ - oczekiwana liczebność w komórce $s$ tablicy kontyngencji, $k$ - liczba estymowanych parametrów.

Analiza wartości „,istotności” (,p-value”) dla każdego z modeli, obliczonej przy założeniu, że funkcja wiarogodności ma rozkład chi-kwadrat powyżej określonej, z góry założonej granicy (najczęściej 0,05 ) świadczy o tym, iż model dostarcza dostatecznie dobrego dopasowania ${ }^{1}$.

Innym zestawem wskaźników przydatnych w ocenie i porównywaniu uzyskanych rozwiązań są miary bezpośrednio oparte na wartości funkcji wiarygodności, obrazujące część zmienności, która jest wciąż niewyjaśniona przez model. Jest to logarytm funkcji wiarygodności oraz kryteria informacyjne (bazujące zarówno na logarytmie funkcji wiarogodności, jak i na jej kwadracie) (Akaike 1987): Akaike (AIC) (wzór 5), bayesowskie (BIC) (wzór 6), jak również zgodne kryterium Akaike (CAIC) (wzór 7). Im niższa jest ich wartość, tym lepszy jest model. W praktycznych zastosowaniach najczęściej wybierany jest model, dla którego BIC osiąga minimum ${ }^{2}$. Wszystkie te testy sprowadzają się do porównań między teoretycznymi częstościami reprezentowanymi przez oszacowane parametry modelu a częstościami zaobserwowanymi w danych empirycznych (Akaike 1987: 317-332).

Kryterium informacyjne Akaike'a (AIC):

$$
A I C=-2 \ln (L)+2 p
$$

\footnotetext{
${ }^{1}$ Wartość „p-value” można również oszacować korzystając z metod bootstrapowych, co pozwala zrezygnować z dość restrykcyjnego założenia dotyczącego rozkładu funkcji wiarogodności.

${ }^{2}$ Przykłady: Paas L.J., Vermunt J.K., Bijmolt T.H.A. (2007), Discrete time discrete state latent Markov modeling for assessing and predicting household acquisition of financial products, ,Journal of the Royal Statistical Society" (series A) vol. 170, no. 4, s. 955-974 Magdison; J., Vermunt J.K., Tran B. (2007), Using a Mixture Latent Markov Model to Analyze Longitudinal U.S. Employment Data Involving Measurement Error, [w:] New Trends in Psychometrics, red. Shigemasu K., Okada A., Imaizum T., Hoshino T. (2007), „Frontiers Science Series”, no. 55, Universal Academy Press Inc., s. 235-242; Kamakura R. Du, W.A. (2006), Household Lifecycles and Life Styles in America, „Journal of Marketing Research”, vol. 43, s. 121-132.
} 
Kryterium Bayesowskie Schwarza (BIC - the Bayesian Information Criterion):

$$
B C I=-2 \ln (L)+p^{*} \ln (N)
$$

Zgodne kryterium informacyjne Akaike'a (CAIC):

$$
C A I C=-2 \ln (L)+p^{*}(1+\ln (N))
$$

gdzie:

$\ln (L)$ - logarytm naturalny funkcji wiarygodności,

$p$ - liczba estymowanych parametrów.

$N$ - liczba obserwacji

W modelach klas latentnych respondent nie jest na stałe przypisywany do segmentu, lecz prawdopodobieństwo przynależności do każdego z wyznaczonych segmentów zostaje dla niego wyliczone.. Zabieg ten umożliwia stosowanie do oceny i porównywania różnych modeli statystyk klasyfikacyjnych bazujących na oszacowanych prawdopodobieństwach. Trafność zdefiniowania stanów i klas ukrytych bada się poprzez sprawdzanie, na ile precyzyjnie można przyporządkować do nich obserwowane obiekty, mając do dyspozycji zmienne wskaźnikowe (Vermunt, Magidson 2005: 14-25). W tym celu oblicza się prawdopodobieństwa przynależności do poszczególnych stanów warunkowe względem wartości zmiennych wskaźnikowych i oszacowanych parametrów. Na ich podstawie oblicza się procent błędnych klasyfikacji oraz kilka rodzajów pseudo-R2 opisujących względny przyrost jakości klasyfikacji do stanów, który uzyskuje się dzięki wykorzystaniu informacji o zmiennych wskaźnikowych. Pseudo-R2 są to przede wszystkim różne odmiany współczynnika R-kwadrat: standardowy czy bazujący na miarach entropii, ale też wskaźnik pozwalający ocenić, na ile dane rozwiązanie obniżyło błędy klasyfikacji w porównaniu z rozwiązaniem bazowym (powstałym bez użycia konkretnego zestawu predyktorów). Syntetycznym wskaźnikiem, który łączy w jedno informacje na temat dopasowania, oszczędności modelu oraz poprawności klasyfikacji, jest wskaźnik AWE (Average Weight of Evidence) (Pass, Vermunt, Bijmolt 2007: 955-974).

\section{ZASTOSOWANIE MODELU KLAS UKRYTYCH W KLASYFIKACJI TYPOLOGICZNEJ ZACHOWAŃ FINANSOWYCH KREDYTOBIORCÓW MIESZKANIOWYCH}

Decyzji dotyczącej wyboru określonej waluty kredytu mieszkaniowego nie można opisać opierając się na jednej zmiennej. Wskaźniki stanów reprezentują przede wszystkim zmienne opisujące uwarunkowania decyzji konsumenckich w tym zakresie. Są to 23 zmienne stanowiące preferencje i korzyści związane 
z wyborem określonej waluty kredytu hipotecznego (tabela 2). Główne obszary oceny stanu dotyczyły stylu życia, wiedzy o finansach, skłonności do podejmowania ryzyka, samooceny obecnej i przyszłej sytuacji ekonomicznej oraz zawodowej, zorientowania na zysk, skłonności do zadłużania się oszczędzania, przezorności, umiejętności planowania i zarzadzania budżetem gospodarstwa domowego, reakcji na ofertę instytucji finansowych, postawy wobec banków, poziomu zaufania do banków oraz sposobu podejmowania decyzji.

W pierwszym kroku konieczne jest jednak określenie liczby skupisk (klas ukrytych). Oszacowano dziewięć alternatywnych modeli zawierających od jednej do dziewięciu klas ukrytych (tabela 1). Wybór liczby klas ukrytych został dokonany poprzez porównanie wartości miar BIC, CAIC oraz wartości błędu klasyfikacji. Najniższą wartość kryteriów informacyjnych BIC i CAIC oraz błędu klasyfikacji osiągnięto dla modelu z pięcioma klasami ukrytymi (tabela 1). Błąd klasyfikacji w przypadku tego rozwiązania wyniósł 0,0183 . W przypadku redukcji lub dodania klas ukrytych nastąpił jego wzrost. Dla modelu z pięcioma klasami ukrytymi także poziom $p$ nie przekroczył wartości 0,05 . Dla modelu 5-klasowego zostały obliczone parametry modelu klas ukrytych przedstawione w tabeli 2.

Tabela 1

Wybrane kryteria dopasowania modelu klas ukrytych

\begin{tabular}{|c|c|c|c|c|}
\hline $\begin{array}{c}\text { Liczba klas } \\
\text { ukrytych }\end{array}$ & $\begin{array}{c}\text { BIC (bayesowskie } \\
\text { kryterium } \\
\text { informacyjne) }\end{array}$ & $\begin{array}{c}\text { AIC (klasyczne } \\
\text { kryterium } \\
\text { Akaike) }\end{array}$ & $\begin{array}{c}\text { CAIC (spójne } \\
\text { kryterium } \\
\text { informacyjne) }\end{array}$ & Błąd klasyfikacji \\
\hline 1 & 55326,2 & 54846,6 & 55475,2 & 0 \\
\hline 2 & 53570,4 & 52901,0 & 53778,4 & 0,0229 \\
\hline 3 & 53036,3 & 52176,9 & 53363,3 & 0,0392 \\
\hline 4 & 52978,1 & 51928,8 & 53354,1 & 0,0256 \\
\hline 5 & 52978,1 & 51738,9 & 53303,1 & 0,0183 \\
\hline 6 & 53013,8 & 51584,7 & 53457,8 & 0,0262 \\
\hline 7 & 53162,9 & 51543,9 & 53665,9 & 0,0402 \\
\hline 8 & 53063,5 & 51254,6 & 53625,5 & 0,0392 \\
\hline 9 & 53195,2 & 51196,5 & 53816,2 & 0,0388 \\
\hline
\end{tabular}

Źródło: Wyniki badań własnych.

Z tabeli 2 wynika także, że wszystkie zmienne w istotny sposób wpływają na dyskryminację ukrytych segmentów. Wskaźniki determinacji modelu pięcioklasowego $\mathrm{R}^{2}$ wskazują, że model pięcioklasowy w największym stopniu wyjaśnia zmienność cech „spontaniczność/planowanie”, „cel bez względu na konsekwencje” oraz ,powaga podejmowania decyzji”. 
Tabela 2

Parametry modeli klas ukrytych

\begin{tabular}{|c|c|c|c|c|c|c|c|}
\hline & $\begin{array}{l}\text { Seg- } \\
\text { ment } 1\end{array}$ & $\begin{array}{l}\text { Seg- } \\
\text { ment } 2\end{array}$ & $\begin{array}{l}\text { Seg- } \\
\text { ment } 3\end{array}$ & $\begin{array}{c}\text { Seg- } \\
\text { ment } 4\end{array}$ & $\begin{array}{l}\text { Seg- } \\
\text { ment } 5\end{array}$ & $\mathrm{p}$-value & $\mathrm{R} 2$ \\
\hline 1 & 2 & 3 & 4 & 5 & 6 & 7 & 8 \\
\hline $\begin{array}{l}\text { spontaniczność/ } \\
\text { planowanie }\end{array}$ & $-0,982$ & 1,083 & $-1,484$ & 1,613 & $-0,231$ & 0,00 & 0,479 \\
\hline $\begin{array}{l}\text { cel bez względu } \\
\text { na konsekwencje }\end{array}$ & $-1,071$ & 0,922 & $-1,264$ & 1,909 & $-0,496$ & 0,00 & 0,475 \\
\hline $\begin{array}{l}\text { powaga podejmowanych } \\
\text { decyzji }\end{array}$ & $-0,749$ & 0,881 & $-1,274$ & 1,610 & $-0,468$ & 0,00 & 0,428 \\
\hline życie dniem dzisiejszym & $-0,258$ & 0,476 & $-1,155$ & 0,301 & 0,635 & 0,00 & 0,379 \\
\hline banki są nierzetelne & 0,555 & $-0,689$ & 0,660 & 0,200 & $-0,726$ & 0,00 & 0,356 \\
\hline oszczędzanie vs kredyt & $-0,334$ & 0,414 & $-1,008$ & 0,385 & 0,543 & 0,00 & 0,355 \\
\hline $\begin{array}{l}\text { rozważanie decyzji } \\
\text { finansowych }\end{array}$ & $-0,501$ & 0,746 & $-1,355$ & 1,168 & $-0,059$ & 0,00 & 0,350 \\
\hline $\begin{array}{l}\text { zainteresowanie } \\
\text { finansami }\end{array}$ & 0,354 & 0,059 & $-0,926$ & 0,371 & 0,143 & 0,00 & 0,324 \\
\hline $\begin{array}{l}\text { awersja do zarządzania } \\
\text { finansami domowymi }\end{array}$ & 0,039 & 0,043 & $-0,938$ & 0,390 & 0,465 & 0,00 & 0,318 \\
\hline motyw zysku & 0,379 & $-0,909$ & 0,520 & $-0,013$ & 0,023 & 0,00 & 0,315 \\
\hline $\begin{array}{l}\text { wiedza o usługach } \\
\text { bankowych }\end{array}$ & $-1,243$ & $-3,010$ & 4,014 & $-2,460$ & 2,699 & 0,00 & 0,252 \\
\hline kontrola wydatków & 0,194 & $-1,737$ & 2,532 & $-1,352$ & 0,362 & 0,00 & 0,231 \\
\hline $\begin{array}{l}\text { samoocena kompetencji } \\
\text { finansowych }\end{array}$ & $-0,696$ & $-0,156$ & 0,300 & $-0,052$ & 0,604 & 0,00 & 0,229 \\
\hline $\begin{array}{c}\text { rozważanie } \\
\text { konsekwencji decyzji }\end{array}$ & $-0,205$ & 0,601 & $-1,137$ & 0,632 & 0,109 & 0,00 & 0,218 \\
\hline $\begin{array}{c}\text { determinacja } \\
\text { do oszczędzania }\end{array}$ & $-0,531$ & $-0,935$ & 2,900 & $-1,257$ & $-0,177$ & 0,00 & 0,207 \\
\hline otwartość na ryzyko & 0,645 & $-0,234$ & 0,060 & 0,296 & $-0,767$ & 0,00 & 0,174 \\
\hline $\begin{array}{l}\text { samowykluczenie wobec } \\
\text { rynku finansowego }\end{array}$ & $-0,026$ & $-0,072$ & $-0,667$ & 0,070 & 0,695 & 0,00 & 0,165 \\
\hline $\begin{array}{l}\text { standard życia za } \\
\text { wszelką cenę }\end{array}$ & $-0,551$ & 0,068 & $-0,172$ & 0,084 & 0,571 & 0,00 & 0,162 \\
\hline $\begin{array}{l}\text { lojalność wobec } \\
\text { dostawcy usług }\end{array}$ & 0,063 & 0,451 & $-0,355$ & 0,217 & $-0,375$ & 0,00 & 0,161 \\
\hline zaufanie do banków & $-0,466$ & $-0,426$ & 0,255 & 0,482 & 0,155 & 0,00 & 0,146 \\
\hline
\end{tabular}


Klasyfikacja typologiczna kredytobiorców hipotecznych z wykorzystaniem modeli... 213

\begin{tabular}{|c|c|c|c|c|c|c|c|}
\hline 1 & 2 & 3 & 4 & 5 & 6 & 7 & 8 \\
\hline $\begin{array}{c}\text { spontaniczne zakupy } \\
\text { na kredyt }\end{array}$ & $-0,479$ & $-0,092$ & $-0,041$ & 0,198 & 0,414 & 0,00 & 0,115 \\
\hline sposób urlopowania & $-0,082$ & 0,410 & $-0,329$ & 0,469 & $-0,468$ & 0,00 & 0,095 \\
\hline $\begin{array}{c}\text { preferowanie wysokiej } \\
\text { jakości }\end{array}$ & $-0,480$ & $-0,764$ & 0,153 & $-0,359$ & 1,450 & 0,00 & 0,089 \\
\hline
\end{tabular}

Źródło: Wyniki badań własnych.

Na podstawie oceny prawdopodobieństwa warunkowego przynależności poszczególnych 23 wskaźników do poszczególnych klas ukrytych zdefiniowano nazwy własne poszczególnych klas ukrytych (segmentów) oraz opracowano profile poszczególnych segmentów.

W wyniku zastosowania modelu pięcioklasowego określono rozmiar poszczególnych segmentów (wykres 1). Najliczniejszy, zarówno w grupie kredytobiorców hipotecznych w PLN (28\%) jak i kredytobiorców hipotecznych w CHF (38\%), jest segment „Zdystansowani”. „Bezkrytyczni” w podobnym są reprezentowani w grupie kredytobiorców PLN jak i CHF, jednak segment „Aspirujący” jest znacznie częściej reprezentowany w grupie kredytobiorców CHF i stanowi 22\% tej grupy. Podobnie segment „Zagubieni” stanowi 15\% w grupie kredytobiorców CHF oraz odpowiednio $6 \% \mathrm{w}$ grupie kredytobiorców PLN.

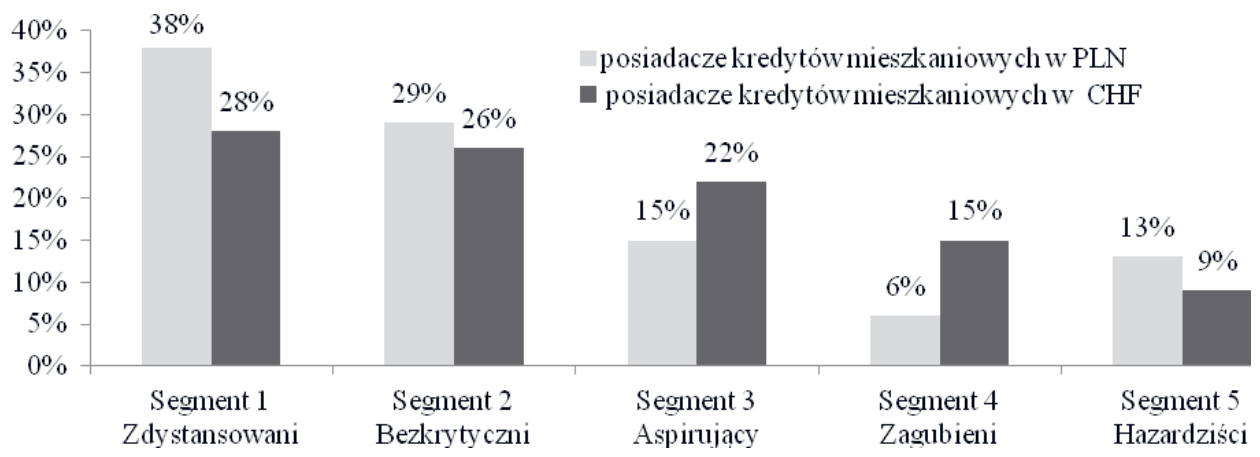

Wykres 1. Klasyfikacja typologiczna posiadaczy kredytów hipotecznych w złotych polskich oraz frankach szwajcarskich

Źródło: Wyniki badań własnych.

Segment 1 „Zdystansowani”: Myślą o przyszłości, starają się podejmować przemyślane decyzje w sprawach finansowych, rozważają ich konsekwencje. Nie są skłonni do podejmowania ryzyka, unikają ryzyka straty. Nie interesują się finansami, mają poczucie, że wiedzą o nich mniej niż ich znajomi. Szukają prostych ofert. Wydają pieniądze na bieżące potrzeby, ale widzą sens oszczędzania. Unikają 
zadłużenia się za wszelką cenę, obawiają się zapożyczać, zaciąganie kredytu nie jest dla nich czymś normalnym. $Z$ dystansem patrzą na banki, mają do nich ograniczone zaufanie. Ocieniają, że w kontaktach z bankami należy zachować ostrożność. Nie obwiniają banków za sytuację kredytobiorców CHF, którzy, ich zdaniem, kierowali się chęcią zysku. Kwota oszczędności r/r 10\% klientów z segmentu wzrosła, natomiast $25 \%$ klientów zmniejszyła się. $57 \%$ klientów posiada kredyt w PLN, średni wiek to 43 lata, przeważają osoby w wykształceniem średnim, $25 \%$ to mieszkańcy wsi, $57 \%$ - mieszkańcy miast powyżej 100 tys. mieszkańców. $33 \%$ to właściciele domów, a $67 \%$ - właściciele mieszkań, 24\% posiada kredyt gotówkowy lub ratalny, 5\% lokatę terminową. 35\% nie widziało żadnych zagrożeń w momencie zaciągania kredytu mieszkaniowego.

Segment 2 „Bezkrytyczni”: Nie myślą o przyszłości, wręcz lubią być zaskakiwani przez życie. Często podejmują decyzje pod wpływem chwili. Kiedy na czymś im zależy, działają bez względu na konsekwencje. Wybierają oferty finansowe, które akurat sa dostępne. Są skłonni do podejmowania ryzyka. Nie czują potrzeby zachowania ostrożności w kontaktach z bankami. Interesują się finansami, jednak nie przywiązują dużej wagi do ich kontrolowania i zarządzania nimi. Często nie wiedzą dokładnie, co mają w banku. Nie mają poczucia, że wiedzą o finansach więcej niż ich znajomi. Bankowość jest dla nich zawiła. Zazwyczaj wydają tyle, ile maja, żyją dniem dzisiejszym. Nie widzą sensu, by oszczędzać i nie starają się tego robić. Mają pewne obawy przed pożyczaniem. Mimo wszystko, planują zaciągnięcie kolejnych kredytów. Wykazują ograniczone zaufanie do banków, obarczają je winą za sytuację kredytobiorców CHF, którzy, ich zdaniem, nie kierowali się chęcią zysku. Kwota oszczędności r/r 2\% klientów z tego segmentu wzrosła, natomiast $29 \%$ zmniejszyła się. W tym segmencie 52\% klientów posiada kredyt w PLN. Ich średni wiek to 41 lat, przeważają osoby w wykształceniem średnim, $27 \%$ to mieszkańcy wsi, $65 \%$ - mieszkańcy miast powyżej 100 tys. mieszkańców. $44 \%$ to właściciele domów, a 55\% - właściciele mieszkań, $15 \%$ posiada kredyt gotówkowy lub ratalny, $1 \%$ lokatę terminową. $12 \%$ nie widziało żadnych zagrożeń w momencie zaciągania kredytu mieszkaniowego.

Segment 3 „Aspirujący”: Myślą o przyszłości i lubią mieć wszystko pod kontrolą. Starannie rozważają decyzje finansowe i ich konsekwencje. Szukają kompleksowych ofert finansowych. Ich stosunek do ryzyka zależy od konkretnej sytuacji. Zwykle kalkulują. Interesują się finansami i śledzą nowe oferty na rynku. Przykładają dużą wagę do zarządzania swoimi środkami, starannie je kontrolują. Wiedzą dokładnie, co mają w banku. Mają też poczucie, że wiedzą o finansach więcej niż ich znajomi. Rozumieją sens oszczędzania i starają się oszczędzać, kiedy tylko mogą. Nie unikają zapożyczania się za wszelką cenę, zaciąganie kredytu to dla nich naturalna sytuacja. Mimo wszystko, poza zakupami na raty, raczej nie planują zaciągnięcia kolejnych kredytów. Banki są dla nich instytucjami godnymi zaufania, jednak w kontaktach z nimi starają się zachowywać ostrożność. Ich zdaniem kredytobiorcy CHF chcieli zyskać na kredycie CHF. Kwota oszczędności 
$\mathrm{r} / \mathrm{r} 18 \%$ klientów z tego segmentu wzrosła, natomiast 22\% zmniejszyła się. $59 \%$ posiada kredyt w CHF, ich średni wiek to 41 lata, przeważają osoby w wykształceniem wyższym, $17 \%$ to mieszkańcy wsi, $78 \%$ - mieszkańcy miast powyżej 100 tys. mieszkańców. 30\% to właściciele domów, a 73\% - właściciele mieszkań, 28\% posiada kredyt gotówkowy lub ratalny, $15 \%$ lokatę terminową, $31 \%$ nie widziało żadnych zagrożeń w momencie zaciągania kredytu mieszkaniowego.

Segment 4 „Zagubieni”: Nie myślą o przyszłości, często podejmują decyzje pod wpływem chwili i nie rozważają ich konsekwencji. Ich zdaniem oferty finansowe niewiele się od siebie różnią, zwykle kryterium wyboru jest cena. Są otwarci na nowe instytucje na ryku finansowym. Raczej wolą niższy, ale pewny zysk. Nie interesują się finansami i nie lubią się nimi zajmować. Kontrola finansów i zarządzanie nimi nie są dla nich ważne. Raczej nie wiedzą dokładnie, co mają w banku. Wydają pieniądze na bieżące potrzeby i nie starają się oszczędzać. Nie mają większych obaw przed pożyczaniem. Kiedy o czymś marzą i mają możliwość wzięcia kredytu, korzystają z okazji. Obecnie nie planują jednak zaciągnięcia kredytu. Ufają bankom, równocześnie jednak myślą o nich jako o „naciągaczach”. Kwota oszczędności r $\mathrm{r}$ r 10\% klientów z tego segmentu wzrosła, natomiast 19\% klientów zmniejszyła się. $71 \%$ posiada kredyt w PLN, średni wiek to 44 lata, udział osób z wykształceniem średnim oraz wyższym są porównywalne, 16\% to mieszkańcy wsi, 75\% - mieszkańcy miast powyżej 100 tys. mieszkańców. 39\% to właściciele domów, a 56\% - właściciele mieszkań. 26\% posiada kredyt gotówkowy lub ratalny, $2 \%$ lokatę terminową. $27 \%$ nie widziało żadnych zagrożeń w momencie zaciągania kredytu mieszkaniowego.

Segment 5 „Hazardziści”: Mają ambiwalentne podejście do szczegółowego rozważania swoich decyzji i ich konsekwencji. Lubią podejmować ryzyko, licząc na wyższy zysk. Zarządzają swoimi finansami, jednak starają się zajmować nimi jak najmniej. Wiedzą dokładnie, co mają w banku i mają silne poczucie, że o finansach wiedzą więcej niż ich znajomi. Zwykle wydają wszystkie pieniądze, żyją dniem dzisiejszym. Nie widzą sensu oszczędzania, jednak czasem starają się odłożyć pewną sumę. Zaciąganie kredytu to dla nich naturalna sytuacja. Kiedy o czymś marzą i mają możliwość wzięcia kredytu, chętnie korzystają z takiej możliwości. Nie mają obaw przed pożyczaniem, jednak raczej starają się unikać zadłużenia. Planują zaciągnięcie kolejnych kredytów, zwłaszcza kredytu gotówkowego. Nie widzą potrzeby, aby w kontaktach z bankami zachowywać ostrożność. Nie obarczają ich również winą za sytuację kredytobiorców frankowych. Kwota oszczędności $\mathrm{r} / \mathrm{r} 1 \%$ klientów z tego segmentu wzrosła, natomiast $39 \%$ klientów zmniejszyła się. 58\% posiada kredyt w PLN, ich średni wiek to 41 lat, przeważają osoby w wykształceniem zawodowym, 26\% to mieszkańcy wsi, 29\% - mieszkańcy miast powyżej 100 tys. mieszkańców. 42\% to właściciele domów, a 57\% - właściciele mieszkań. 16\% posiada kredyt gotówkowy lub ratalny, 9\% - lokatę terminową. $26 \%$ nie widziało żadnych zagrożeń w momencie zaciągania kredytu mieszkaniowego. 


\section{WYBRANE ASPEKTY DECYZJI KONSUMENTÓW I PROCESU DECYZYJNEGO WYBORU WALUTY KREDYTU HIPOTECZNEGO}

Pod względem socjodemograficznym kredytobiorcy walutowi i spłacający kredyty w złotych polskich stanowią grupę niemal homogeniczną. Cechy socjodemograficzne nie wyjaśniają decyzji podejmowanych przez konsumentów w procesie kredytowym. Podstawową linię podziału między analizowanymi grupami kredytobiorców wyznacza waluta kredytu oraz szukanie przez konsumentów optimum pomiędzy ceną kredytu a bezpieczeństwem. Dominującym motywem w kwestii wyboru waluty w przypadku kredytobiorców złotowych było bezpieczeństwo i awersja do ryzyka walutowego (95\%), a w przypadku kredytobiorców walutowych - wysokość rat kredytu ( $65 \%$ wskazań). Kredytobiorcy złotowi wybierali opcję, ich zdaniem, bardziej bezpieczną. Kredytobiorcy walutowi częściej kierowali się interesem ekonomicznym. Zarówno jedna jak i druga grupa była świadoma różnych rodzajów ryzyka. Istotnym czynnikiem ryzyka okazał się jednak przeszacowany optymizm. Kredytobiorcy CHF zdecydowanie niżej oceniali ryzyko wzrostu kursu walut i ryzyko związane z globalnym kryzysem na rynkach finansowych niż kredytobiorcy PLN. Ponadto kredytobiorcy CHF zdecydowanie częściej niż kredytobiorcy PLN oczekiwali poprawy swojej sytuacji zawodowej oraz ekonomicznej w przyszłości. Istotnym czynnikiem różnicującym okazała się postawa prokonsumpcyjna $\mathrm{w}$ grupie kredytobiorców CHF wobec postawy prooszczędnościowej w grupie kredytobiorców PLN, a także większe otwarcie na ryzyko w grupie CHF w stosunku do grupy kredytobiorców PLN. Ponadto kredytobiorcy CHF częściej kalkulowali ekonomiczne efekty kredytu CHF niż klienci zaciągający kredyty w PLN.

Decyzja o wyborze waluty kredytu podejmowana była przez obie grupy kredytobiorców z należytą powagą, wykorzystaniem wiedzy i środków dostępnych kredytobiorcom w momencie zaciągania kredytu. Kredytobiorcy podejmowali aktywne i świadome działania, analizując różne rodzaje ryzyka, w tym ryzyko walutowe, stopy procentowej, sytuacji gospodarstwa domowego na tle ogólnych warunków ekonomicznych, ryzyko utraty pracy itp. Decyzja kredytowa była konsultowane z rodziną lub z kimś doświadczonym.

Decyzja o wyborze waluty kredytu nie była pochopna i w większości przypadków podjęta jeszcze przed udaniem się do banku lub firmy pośrednictwa kredytowego. Jednak kredytobiorcy zamierzający złożyć wniosek o kredyt w złotych byli bardziej konsekwentni. O tym, że kredyt będzie w złotych, trzy czwarte z nich zdecydowało wcześniej, jeszcze przed pójściem do banku czy pośrednika kredytowego. Kredytobiorcy walutowi mieli wcześniej wyrobione zdanie w $60 \%$ przypadków.

Niemal wszyscy kredytobiorcy porównywali oferty różnych banków, a większość porównywała też oferty kredytów złotowych i walutowych $(58 \%$ 
kredytobiorców złotowych i 86\% walutowych). Kredytobiorcy walutowi porównywali oferty kredytu ze względu na rodzaj waluty częściej niż złotowi, szukając dla siebie najbardziej atrakcyjnej oferty.

Ośmiu na dziesięciu kredytobiorców walutowych twierdzi, że zdawała sobie sprawę z możliwego wpływu zmiany kursu waluty na wartość zobowiązania i rat kredytu. Taką samą opinię prezentuje również $73 \%$ tych osób, które rozważały kredyt w walucie, ale zdecydowały się na kredyt w złotych. Kredytobiorcy złotowi, którzy rozważali kredyt walutowy, najczęściej obawiali się wzrostu kursu waluty, co skutecznie zniechęcało ich do kredytu walutowego. Kredyty złotowe rozważało natomiast $2 / 3$ kredytobiorców walutowych. W zdecydowanej większości (68\%) rezygnowali oni jednak z kredytu złotowego, argumentując decyzję brakiem opłacalności takiego rozwiązania.

Zdecydowana większość kredytobiorców ocenia, że uważnie przeczytała warunki umowy i były one dla niej zrozumiałe. W grupie kredytobiorców złotowych takie odpowiedzi padają częściej (95\%) niż w grupie kredytobiorców walutowych (86\%). Ponadto 41\% kredytobiorców złotowych i 50\% kredytobiorców walutowych uważa, że banki rzetelnie informowały o ryzyku walutowym, przeciwnego zdania jest odpowiednio 21\% i 25\% kredytobiorców. Rozkład odpowiedzi kredytobiorców na pytania, czy oni sami byli informowani o ryzyku walutowym jest jednak diametralnie różny. $74 \%$ osób, które zdecydowały się na kredyt w walucie twierdzi, że to doradca w banku powiedział im o ryzyku walutowym. Tak samo odpowiada też $68 \%$ osób, które rozważały kredyt walutowy, ale ostatecznie zdecydowały się na kredyt w złotych.

Średnie ważone obciążenie budżetu domowego ratą kredytu hipotecznego gospodarstwa domowego w grupie kredytobiorców złotowych to $27,1 \% \mathrm{w}$ momencie zaciągania kredytu i 25,8\% w momencie realizacji badania. Dla kredytobiorców walutowych to odpowiednio $22,4 \%$ i $28,1 \%$.

\section{PODSUMOWANIE}

Na podstawie przeprowadzonych analiz istnieją podstawy do odrzucenia hipotezy, że konsumenci spłacający kredyty walutowe stanowią grupę homogeniczną. Pod względem socjodemograficznym to względnie jednolita grupa, lecz silnie zróżnicowana pod względem psychograficznym oraz ze względu na motywy podejmowania decyzji o wyborze waluty kredytu. Klasyfikacja typologiczna ujawniła 5 różnych segmentów kredytobiorców wyróżnionych ze względu na profil psychograficzny, postawy wobec ryzyka, wiedzę o finansach, przezorność, skłonność do zadłużania się i oszczędzania, uwarunkowania zaufania do banków.

Model klas ukrytych umożliwił identyfikację podtypów cech powiązanych ze sobą, które pozwalają na poznanie uwarunkowań decyzji konsumentów związanych z wyborem waluty kredytu hipotecznego. 
Wyniki analizy modeli klas ukrytych mogą służyć do lepszego poznania złożonych zjawisk społecznych na runku finansowym, wspomagać proces komunikacji i identyfikacji potencjalnych zagrożeń.

Główne zróżnicowania grupy kredytobiorców wynikają z postaw wobec rynku finansowego, percepcji potencjalnego ryzyka w momencie zaciągania kredytu oraz w przyszłości, preferencji wobec ryzyka oraz reakcji na ofertę kredytów mieszkaniowych.

Kredytobiorcy spłacający kredyty mieszkaniowe w PLN kierowali się motywem bezpieczeństwa, natomiast kredytobiorcy CHF motywem ekonomicznym.

Uzyskane rezultaty pozwoliły odnieść się do wybranych uogólnień i opinii funkcjonujących w przestrzeni publicznej, wskazać uwarunkowania decyzji kredytowych oraz wydzielić kilka zróżnicowanych pod tym względem grup kredytobiorców . To zróżnicowanie wyjaśnia niechęć kredytobiorców walutowych do identyfikowania się z ogólnymi opiniami na temat nieprzemyślanego i nonszalanckiego zachowania samych kredytobiorców, a także nieodpowiedzialnego działania banków.

\section{BIBLIOGRAFIA}

Akaike H. (1987), Factor analysis and AIC, "Psychometrika", vol. 52.

Antonides G., van Raaij W.F. (1998), Consumer Behaviour. A European Perspective, John Wiley \& Sons, New York.

Bańbuła P. (2006), Oszczędności i wybór międzyokresowy: podejście behawioralne, „Materiały i Studia" 2006, nr 208, Narodowy Bank Polski, Warszawa 2006.

Bartholomew D.J., Knott M. (2002), Latent Variable Models and Factor Analysis, Arnold.

Bollen K. (1989), Structural equations with latent variables, New York, Wiley.

Browning M., Lusardi A. (1996), Household saving: micro teories and micro facts, „Journal of Economic Literatur", vol. 34.

Dempster A.P., Laird N.M., Rubin D.B. (1997), Maximum Likelihood from incomplete data via EM algorithm, „Journal of the Royal Statistical Society” (series B), vol. 39, no. 1.

Formann A.K. (2003), Latent class model diagnostics-A review and some proposals. Computational, Statistics \& Data Analysis, vol. 41.

Hagenaars J.A., McCutcheon A.L. (2002), Applied Latent Class Analysis, Cambridge University Press.

Kamakura Du R. W.A. (2006), Household Lifecycles and Life Styles in America, „Journal of Marketing Research", vol. 43.

Kaplan D. (2003), Latent Class Models, Forthcoming. "Handbook for Quantitative Methodology", Sage.

Keel P., Fichter M., Quadflieg, N., Bulik C., Baxter M., Thornton L. (2004). Application of a latent class analysis to empirically define eating disorder phenotypes, "Psychiatry", vol. 61.

Keynes J.M. (1936), The general teory of employment, interest and money, MacMillan, London.

Langeheine R. van de Pol F. (2002), Latent Markov Chains, “Applied Latent Class Analysis”, red. J.A. Hagenaars, A.L. McCutcheon, Cambridge University Press, New York. 
Lubke G.H., Muthén B. (2005), Investigating population heterogeneity with factor mixture models. "Psychological Methods", vol. 10.

Magdison J., Vermunt J.K., Tran B. (2007), Using a Mixture Latent Markov Model to Analyze Longitudinal U.S. Employment Data Involving Measurement Error, w: New Trends in Psychometrics, red. Shigemasu K., Okada A., Imaizum T., Hoshino T., „Frontiers Science Series” 2007, no. 55, Universal Academy Press Inc.

Paas L.J., Vermunt J.K., Bijmolt T.H.A. (2007), Discrete time discrete state latent Markov modeling for assessing and predicting household acquisition of financial products, ,Journal of the Royal Statistical Society" (series A), vol. 170, no. 4.

Shefrin H.M., Thaler R.H. (1988), The behavioral life-cycle hypothesis, „Economic Inquiry”, vol. 26 (4), Oxford University Press.

Singh A. (2010), Market segmentation in FMCG: time to drive new basis for market segmentation, "International Journal of Research in Commerce \& Management", vol. 1, no. 8.

Smith W. (1956), Product differentiation and market segmentation as alternative marketing strategies, "Journal of Marketing", vol. 21.

Thaler R.H., Shefrin H. M. (1981), An Economic Theory of Self-Control, „Journal of Political Economy", vol. 89(2), University of Chicago Press.

Tofighi D., Enders C.K. (2007), Identifying the correct number of classes in a growth mixture model, [w:] G.R. Hancock (ed.), Mixture models in latent variable research, Greenwich.

Vermunt J., Magidson J. (2003), Encyclopedia of Social Science Research Methods, Sage Publications: Vermunt

Vermunt J.K., Magidson J. (2005), Technical Guide for Latent GOLD 4.0: Basic and Advanced, Statistical Innovations, Belmont.

Vermunt J.K., Magidson J. (2008), LG-Syntax User's Guide: Manual for Latent GOLD 4.5 Syntax Module, Statistical Innovations, Belmont.

Webley P., Nyhus E.K. (2001), Representations of Saving and Saving Behaviour, w: Everyday Representations of the Economy, red. Ch. Roland-Levy, E. Kirchler, E. Penz, C. Gray, WUV Universitatsverlag, Wien.

Yang C. (2006), Evaluating latent class analyses in qualitative phenotype identification, "Computational Statistics \& Data Analysis", vol. 50.

\section{Marcin Idzik, Jacek Gieorgica}

\section{TYPOLOGICAL CLASSIFICATION OF THE MORTGAGE BORROWERS WITH THE USE OF THE LATENT CLASS MODELS}

\footnotetext{
Abstract. The holders of the mortgage loans constitute more than 6 percent of the individual customers of banks. In a wide-spread opinion, this group is regarded as homogeneous; however, the sociodemographic features not only do not explain, but actually conceal the diversified circumstances of the decisions made by the mortgage borrowers on the financial market. The diversifying factors are as follows: the psychographic profile, the attitude towards taking risks, the knowledge about the finances, caution, the inclination to get indebted and make savings. The objective of the research was to isolate homogeneous segments of the mortgage loan holders in terms of the circumstances of making consumer decisions on the financial market. Five homogeneous groups of mortgage borrowers were selected in terms of circumstances and motives behind the decisions on the financial market. This segmentation was conducted using latent class models (LCA). Latent class models
} 
enabled us to identify the feature subtypes connected with each other which are not recorded in a traditional approach. The research was conducted using a CAPI method on a nation-wide representative sample of mortgage loan holders of $\mathrm{N}=900$, out of which $\mathrm{N}=800$ were borrowers in Swiss francs, and $\mathrm{N}=100$ were borrowers in Polish zlotys. The research was conducted by TNS Polska in March 2014 and second wave in March 2015 r.

Keywords: mortgage borrowers, typological classification, latent class models. 